\title{
COMPARATIVE STUDY BETWEEN INTRAVENOUS DEXAMETHASONE VERSUS KETAMINE GARGLE VERSUS INTRAVENOUS DEXAMETHASONE COMBINED WITH KETAMINE GARGLE FOR EVALUATION OF POST-OPERATIVE SORE THROAT AND HOARSENESS IN MIDDLE EAR SURGERY
}

\author{
Surendra K. Raikwar', Rajkumar Ahirwal'2, Sweety Bhola ${ }^{3}$ \\ ${ }^{1}$ Associate Professor, Department of Anaesthesiology, Gandhi Medical College and Associated Hospitals, Bhopal, Madhya Pradesh. \\ ${ }^{2}$ Assistant Professor, Department of Anaesthesiology, Gandhi Medical College and Associated Hospitals, Bhopal, Madhya Pradesh. \\ ${ }^{3}$ Resident, Department of Anaesthesiology, Gandhi Medical College and Associated Hospitals, Bhopal, Madhya Pradesh.
}

\section{ABSTRACT}

\section{BACKGROUND}

Endotracheal intubation is the common cause of trauma to the airway mucosa, resulting in post-operative sore throat (POST) and hoarseness. This study was done to evaluate and compare the effectiveness of prophylactically used dexamethasone-ketamine combination compared with IV dexamethasone/ ketamine-gargle alone in POST and hoarseness in patients undergoing elective middle ear surgery receiving general anaesthesia with endotracheal intubation.

\section{MATERIALS AND METHODS}

This was a prospective, randomised, placebo-controlled and double-blinded clinical study, in which 80 patients (as per convenience as there are 4 groups in my study and availability of patients who meet with the study criteria) aged (16 - 45 yrs.) ASA grade I and II were posted for middle-ear surgery. They were randomly assigned with informed consent into 4 groups (n= 20); Group K: gargled $40 \mathrm{mg}$ ketamine in $30 \mathrm{~mL}$ NS for $30 \mathrm{sec}$; Group D: gargled $30 \mathrm{~mL}$ normal saline for $30 \mathrm{sec}$, received $0.2 \mathrm{mg} / \mathrm{kg}$ IV dexamethasone, Group KD: gargled $40 \mathrm{mg}$ ketamine in $30 \mathrm{~mL}$ NS for $30 \mathrm{sec}$ and received $0.2 \mathrm{mg} / \mathrm{kg}$ IV dexamethasone and Group P: gargled $3 \mathrm{~mL}$ NS for 30s, received IV NS (all measures were done 5 mins before induction. POST and hoarseness were graded post-operatively at $0,1,6,12$ and $24 \mathrm{hrs}$.).

\section{RESULTS}

The incidence and severity of POST were significantly lower in Group KD compared with other groups at all times during 24 hrs. post-operatively. Also, the incidence and severity of hoarseness were significantly lower in each one of Groups of KD, K and D compared with Group P. But no significant differences between Groups KD with Group K and Group D. Most of the patients of Group P suffered from POST and hoarseness.

\section{CONCLUSION}

For reducing incidence and severity of POST and hoarseness, administration of ketamine-gargle combined with IV dexamethasone was more effective than using each of these drugs alone at all times after extubation.

\section{KEYWORDS}

Endotracheal Intubation, Post-Operative Sore Throat (POST) and Hoarseness, IV Dexamethasone, Ketamine-Gargle, Middle Ear Surgery.

HOW TO CITE THIS ARTICLE: Raikwar SK, Ahirwal R, Bhola S. Comparative study between intravenous dexamethasone versus ketamine gargle versus intravenous dexamethasone combined with ketamine gargle for evaluation of post-operative sore throat and hoarseness in middle ear surgery. J. Evolution Med. Dent. Sci. 2018;7(13):1639-1643, DOI: 10.14260/jemds/2018/370

\section{BACKGROUND}

Endotracheal intubation is the most common cause of trauma to airway mucosa, resulting in post-operative sore throat (POST) and hoarseness. Incidence of sore throat- 21\%$65 \% .{ }^{[1]}$ These are the most undesirable outcomes influencing patient's satisfaction and activities, and leaving an unpleasant memory of operation to the patients.

Despite attempts to reduce its incidence and severity, there are currently no effective therapies for the prevention of POST and hoarseness. Various trials (non-pharmacological methods) have been used for reducing POST with variable success. Like smaller sized ET tubes, use of lubricating water'Financial or Other Competing Interest': None.

Submission 06-12-2017, Peer Review 10-03-2018,

Acceptance 16-03-2018, Published 26-03-2018.

Corresponding Author:

Dr. Rajkumar Ahirwal,

House No. 88/23, Second Stop, Tulsi Nagar,

Bhopal-462003, Madhya Pradesh.

E-mail: drrajkumarahirwal@ymail.com

DOI: $10.14260 /$ jemds $/ 2018 / 370$

soluble jelly, careful airway instrumentation, intubation after full relaxation, minimised intracuff pressure, gentle under vision oropharyngeal suctioning and extubation when the tracheal tube cuff is fully deflated. These have been reported to decrease the incidence of POST.[2]

The pharmacological methods used for reducing POST: Steroid gel,[3] azulene sulphate, [4] ketamine gargle and steroid injections. $[5,6,7]$

So, we designed this present study to evaluate prophylactic effect of using dexamethasone- ketamine combination compared with using IV dexamethasone or ketamine gargle alone on the post-operative POST and hoarseness.

\section{MATERIALS AND METHODS}

The study was a prospective, randomised, placebo-controlled and double-blind clinical study in Dept. of Anaesthesiology at Hamidia Hospital, Bhopal, over a period of 6 months.

After obtaining approval from Ethical Committee and individual written informed consent, 80 consecutive patients aged (16 - 45 yrs.) ASA grade I and II posted for middle ear 
surgery under General Anaesthesia, patients with the help of a computer-generated table of random numbers were randomised into 4 groups-

Group K (n= 20): Who gargled $40 \mathrm{mg}$ ketamine in $30 \mathrm{~mL}$ NS for $30 \mathrm{sec}$.

Group D (n= 20): Who gargled $30 \mathrm{~mL}$ NS for $30 \mathrm{sec}$ and received $0.2 \mathrm{mg} / \mathrm{kg}$ IV dexamethasone.

Group KD (n= 20): Who gargled $40 \mathrm{mg}$ ketamine in $30 \mathrm{~mL}$ NS and received $0.2 \mathrm{mg} / \mathrm{kg}$ IV dexamethasone.

Group P (n= 20): Who gargled $30 \mathrm{~mL}$ NS for $30 \mathrm{sec}$ and receive IV NS.

\section{Inclusion Criteria}

1. ASA grade I and II.

2. Age- 16 to 45 yrs.

3. Mouth opening of $>3.5 \mathrm{~cm}$.

4. Patients w/o history of POST and asthma, known allergies to study drugs, known difficulty with tracheal intubation.

\section{Exclusion Criteria}

1. Requirement of mechanical lung ventilation after surgery in ICU.

2. Who required $>1$ attempt for tracheal intubation.

\section{Preparation and Procedure}

The preparations of $30 \mathrm{~mL}$ each were placed in an opaque container by a staff nurse, who also asked patients to gargle with the preparation for $30 \mathrm{sec}$ after their arrival in the operation room and another study drug (Dexamethasone or NS) was injected IV, 5 mins before induction of anaesthesia. The same technique of anaesthesia operated on all patients. Induction of anaesthesia was done after 5 mins.

\section{Monitoring}

Non-invasive arterial pressure, Pulse oximetry (SPO2), Heart Rate, ECG, Et-CO2.

\section{All Patients underwent a Standardised Anaesthesia Protocol which included-}

- IV $0.04 \mathrm{mg} / \mathrm{kg}$ midazolam and glycopyrrolate 0.01 $\mathrm{mg} / \mathrm{kg}$.

- Induction with propofol (2 $\mathrm{mg} / \mathrm{kg})$ and fentanyl (2 $\mu \mathrm{g} / \mathrm{kg}$ ).

- Atracurium was used as a muscle relaxant. Tracheal intubation was performed with a soft seal cuffed sterile ET tube, an ID of $7-7.5 \mathrm{~mm}$ for women and $8-8.5 \mathrm{~mm}$ for men. ET tube cuff pressure was maintained between $18 \mathrm{~cm}-22 \mathrm{~cm} \mathrm{H}_{2} \mathrm{O}$ using hand-held pressure gauge (Endotest; Rüsch, Kernen, Germany). No air leakage could be heard with a peak airway pressure at $20 \mathrm{~cm}$ $\mathrm{H}_{2} \mathrm{O}$.

- Maintenance with 50\% nitrous oxide and 50\% 02 mixture along with isoflurane $(0.5 \% \quad-1 \%)$. Ventilation was adjusted to produce normocapnia. IV fentanyl infusion $0.5 \mu \mathrm{g} / \mathrm{kg} / \mathrm{hr}$ in $50 \mathrm{~mL}$ NS was given. Reversal at the end of surgery was done with IV glycopyrrolate $0.01 \mathrm{mg} / \mathrm{kg}$ and neostigmine 0.05 $\mathrm{mg} / \mathrm{kg}$.

- Oropharyngeal suction was done under direct vision to avoid trauma to the tissues before extubation and to confirm that the clearance of secretions was completed.
All patients were carefully extubated when they were able to obey commands and lung ventilation seemed adequate.

The following Variables Regarding Tracheal Intubation were Recorded

- Glottis exposure as defined by Cormack and Lehane score;

- Endotracheal tube size;

- The time to achieve intubation;

- The duration of tracheal extubation.

The patients were interviewed and assessed for recovery by a blinded observer.

On arrival in the post-anaesthesia care unit at $0 \mathrm{hr}, 1 \mathrm{hr}, 3$ hrs., 6 hrs., 12 hrs. and 24 hrs., POST and hoarseness were recorded thereafter.

\section{Post was graded on a Four-Point Scale (0 - 3)}

- $\quad 0$ - No sore throat;

- 1 - Mild sore throat (Complains of sore throat only on asking);

- 2- Moderate sore throat (Complains of sore throat on his/ her own);

- 3- Severe sore throat (Change of voice/ hoarseness, associated with throat pain).

Hoarseness (As a Change in Voice Quality) was graded on a Four-Point Scale (0-3)

- 0 : No hoarseness;

- 1 : Hoarseness at the time of interview, but noted only by patient;

- 2: Hoarseness that is readily apparent, but mild;

- 3: Hoarseness that is readily apparent and severe.

Sedation was assessed during interviewing the patients to investigate the POST using the four-point observer's assessment of alertness/ sedation scale.

(Where $0=$ awake $/$ alert and $3=$ deep sleep).

Any complication (e.g. peptic ulcer, frequency of infections and electrolyte imbalance) associated with a single use of dexamethasone was obtained from review of the medical record. Other side effects, if any, were also noted.

\section{Statistical Analysis}

Differences in the age and weight among the groups were compared by One-Way Analysis of Variance. Differences in the incidence and severity of POST among the groups were compared with the help of Fisher's exact test. SPSS 16 for windows (SPSS Inc., Chicago, IL, USA) was used for statistical analysis. $\mathrm{P}<0.05$ was considered as significant.

\section{RESULTS}

- The incidence and severity of POST were significantly lower in Group KD (10\%) compared with the other groups [K (26\%) and D (20\%)] at all times during $24 \mathrm{~h}$ after the tracheal extubation $(\mathrm{p}<0.05)$ (Diagram 1, Chart 1, Table 3).

- Also, the incidence and severity of hoarseness were significantly lower in each groups of KD $(10 \%)$ and $\mathrm{K}$ (25\%) and D (16\%) compared with Group P (49\%) at all 
times after tracheal extubation for up to $24 \mathrm{hrs} .(\mathrm{p}<0.05)$ (Diagram 1, Chart 2, Table 3).

- Most of the patients of Group P suffered from POST (44\%) and hoarseness (49\%). No local or systemic sideeffects were observed. Only one patient in Group P had vomiting.

- $\quad$ Out of the 80 enrolled patients 1 patient from Group P was excluded from the analysis, because of difficulty during intubation. Demographic data for the 79 patients are shown in Table 1.

- $\quad$ There were no significant differences among the four groups with respect to age, sex, weight, ASA Grade, duration of surgery, duration of anaesthesia, recovery and sedation score $(\mathrm{p}>0.05)$. Variables associated with tracheal intubation are listed in Table 2.

\begin{tabular}{|c|c|c|c|c|}
\hline Group Variable & Group K (n= 20) & Group D (n= 20) & Group KD (n= 20) & Group P (n= 19) \\
\hline Age (Years) & $28.8 \pm 8.18$ & $27.85 \pm 8.02$ & $29.2 \pm 7.43$ & $28.6 \pm 8.7$ \\
\hline Weight (kg) & $51.7 \pm 10.08$ & $47.85 \pm 11.52$ & $46.75 \pm 10.37$ & $51.36 \pm 12.27$ \\
\hline Sex (M/F) & $11 / 9$ & $8 / 12$ & $13 / 7$ & $9 / 10$ \\
\hline ASA (I/II) & $14 / 6$ & $12 / 8$ & $15 / 5$ & $11 / 8$ \\
\hline Duration of Operation (min) & $81.38 \pm 13.48$ & $82.5 \pm 12.27$ & $84.16 \pm 11.66$ & $82.35 \pm 10.6$ \\
\hline $\begin{array}{c}\text { Duration of } \\
\text { Anaesthesia (min) }\end{array}$ & $99.4 \pm 8.95$ & $100.2 \pm 7.52$ & $101.8 \pm 6.70$ & $103.31 \pm 9.06$ \\
\hline Recovery Time (min) & $25.5 \pm 7.06$ & $23.77 \pm 5.61$ & $23.5 \pm 6.44$ & $24.52 \pm 6.40$ \\
\hline \multicolumn{7}{|r|}{ Table 1. Demographic Data Related to Surgery } \\
\hline
\end{tabular}

(Data are given as Mean \pm SD. ASA- American Society of Anesthesiologists, SD: Standard Deviation)

\begin{tabular}{|c|c|c|c|c|}
\hline Group Variable & Group K (n= 20) & Group D (n= 20) & Group KD (n= 20) & Group P (n= 19) \\
\hline $\begin{array}{c}\text { Cormack and Lehane Score } \\
(1 / 2 / 3)\end{array}$ & $15 / 4 / 1$ & $16 / 4 / 0$ & $14 / 4 / 2$ & $15 / 3 / 1$ \\
\hline ET tube size (7/7.5/8/8.5) & $6 / 3 / 9 / 2$ & $8 / 4 / 4 / 4$ & $4 / 3 / 10 / 3$ & $6 / 4 / 5 / 4$ \\
\hline Time to Achieve Intubation (sec) & $19.12 \pm 4.07$ & $18.70 \pm 4.30$ & $20.24 \pm 4.24$ & $18.10 \pm 3.87$ \\
\hline Extubation Time (sec) & $12.85 \pm 4.42$ & $10.9 \pm 3.46$ & $11.5 \pm 4.04$ & $12.26 \pm 3.52$ \\
\hline \multicolumn{4}{|r}{} \\
\hline
\end{tabular}

(Data are given as Mean \pm SD. ET: Endotracheal)

\begin{tabular}{|c|c|c|c|c|c|}
\hline Variables & $\begin{array}{l}\text { Group D } \\
(n=20)\end{array}$ & $\begin{array}{l}\text { Group K } \\
(n=20)\end{array}$ & $\begin{array}{c}\text { Group KD } \\
(n=20)\end{array}$ & $\begin{array}{l}\text { Group P } \\
(n=19)\end{array}$ & $P$ value \\
\hline $\begin{array}{c}0 \mathrm{hr} \text { after Tracheal } \\
\text { Extubation }\end{array}$ & $\begin{array}{c}18 / 2 / 0 / 0 \\
(10 \%)\end{array}$ & $\begin{array}{c}16 / 3 / 1 / 0 \\
(20 \%)\end{array}$ & $\begin{array}{c}19 / 1 / 0 / 0 \\
(5 \%)\end{array}$ & $\begin{array}{c}13 / 4 / 3 / 0 \\
(35 \%)\end{array}$ & 0.028 \\
\hline Sore Throat $(0 / 1 / 2 / 3)$ & $19 / 1 / 0 / 0$ & $16 / 4 / 0 / 0$ & $19 / 1 / 0 / 0$ & $14 / 3 / 3 / 0$ & 0.022 \\
\hline Hoarseness $(0 / 1 / 2 / 3)$ & $(5 \%)$ & $(20 \%)$ & $(5 \%)$ & $(30 \%)$ & \\
\hline $\begin{array}{c}1 \mathrm{hr} \text { after Tracheal } \\
\text { Extubation }\end{array}$ & $\begin{array}{c}17 / 3 / 0 / 0 \\
(15 \%)\end{array}$ & $\begin{array}{c}16 / 3 / 1 / 0 \\
(20 \%)\end{array}$ & $\begin{array}{c}19 / 1 / 0 / 0 \\
(5 \%)\end{array}$ & $\begin{array}{c}12 / 6 / 2 / 0 \\
(40 \%)\end{array}$ & 0.031 \\
\hline Sore Throat $(0 / 1 / 2 / 3)$ & $18 / 2 / 0 / 0$ & $17 / 3 / 0 / 0$ & $19 / 1 / 0 / 0$ & $14 / 3 / 3 / 0$ & 0.034 \\
\hline Hoarseness $(0 / 1 / 2 / 3)$ & $(10 \%)$ & $(15 \%)$ & (5\%) & $(30 \%)$ & \\
\hline $\begin{array}{c}3 \text { hrs. after Tracheal } \\
\text { Extubation }\end{array}$ & $\begin{array}{c}16 / 4 / 0 / 0 \\
(20 \%)\end{array}$ & $\begin{array}{c}15 / 4 / 1 / 0 \\
(25 \%)\end{array}$ & $\begin{array}{c}19 / 1 / 0 / 0 \\
(5 \%)\end{array}$ & $\begin{array}{c}12 / 4 / 2 / 2 \\
(40 \%)\end{array}$ & 0.023 \\
\hline Sore Throat $(0 / 1 / 2 / 3)$ & $18 / 2 / 0 / 0$ & $16 / 4 / 0 / 0$ & $18 / 2 / 0 / 0$ & $12 / 6 / 2 / 0$ & 0.020 \\
\hline Hoarseness $(0 / 1 / 2 / 3)$ & $(10 \%)$ & $(20 \%)$ & $(10 \%)$ & $(40 \%)$ & \\
\hline $\begin{array}{c}6 \text { hrs. after Tracheal } \\
\text { Extubation }\end{array}$ & $\begin{array}{c}16 / 4 / 0 / 0 \\
(20 \%)\end{array}$ & $\begin{array}{l}15 / 5 / 0 / 0 \\
(25 \%)\end{array}$ & $\begin{array}{l}20 / 0 / 0 / 0 \\
(0 \%)\end{array}$ & $\begin{array}{c}13 / 3 / 4 / 0 \\
(35 \%)\end{array}$ & 0.011 \\
\hline Sore Throat $(0 / 1 / 2 / 3)$ & $16 / 4 / 0 / 0$ & $16 / 1 / 2 / 1$ & $19 / 1 / 0 / 0$ & $11 / 6 / 1 / 2$ & 0.026 \\
\hline Hoarseness $(0 / 1 / 2 / 3)$ & $(20 \%)$ & $(20 \%)$ & $(5 \%)$ & $(45 \%)$ & \\
\hline $\begin{array}{l}12 \mathrm{hrs} \text {. after Tracheal } \\
\text { Extubation }\end{array}$ & $\begin{array}{c}17 / 3 / 0 / 0 \\
(15 \%)\end{array}$ & $\begin{array}{c}16 / 4 / 0 / 0 \\
(20 \%)\end{array}$ & $\begin{array}{c}19 / 1 / 0 / 0 \\
(5 \%)\end{array}$ & $\begin{array}{c}12 / 2 / 4 / 0 \\
(40 \%)\end{array}$ & 0.040 \\
\hline Sore Throat $(0 / 1 / 2 / 3)$ & $17 / 1 / 2 / 0$ & $16 / 3 / 1 / 0$ & $18 / 2 / 0 / 0$ & $12 / 5 / 2 / 1$ & 0.041 \\
\hline Hoarseness $(0 / 1 / 2 / 3)$ & $(15 \%)$ & $(20 \%)$ & $(10 \%)$ & $(40 \%)$ & \\
\hline $\begin{array}{c}24 \text { hrs. after Tracheal } \\
\text { Extubation }\end{array}$ & $\begin{array}{c}16 / 4 / 0 / 0 \\
(20 \%)\end{array}$ & $\begin{array}{c}16 / 4 / 0 / 0 \\
(20 \%)\end{array}$ & $\begin{array}{c}19 / 1 / 0 / 0 \\
(5 \%)\end{array}$ & $\begin{array}{c}13 / 4 / 3 / 0 \\
(35 \%)\end{array}$ & 0.037 \\
\hline Sore Throat $(0 / 1 / 2 / 3)$ & $17 / 3 / 0 / 0$ & $16 / 1 / 3 / 0$ & $18 / 2 / 0 / 0$ & $12 / 5 / 1 / 2$ & 0.043 \\
\hline Hoarseness $(0 / 1 / 2 / 3)$ & $(15 \%)$ & $(20 \%)$ & $(10 \%)$ & $(40 \%)$ & \\
\hline
\end{tabular}




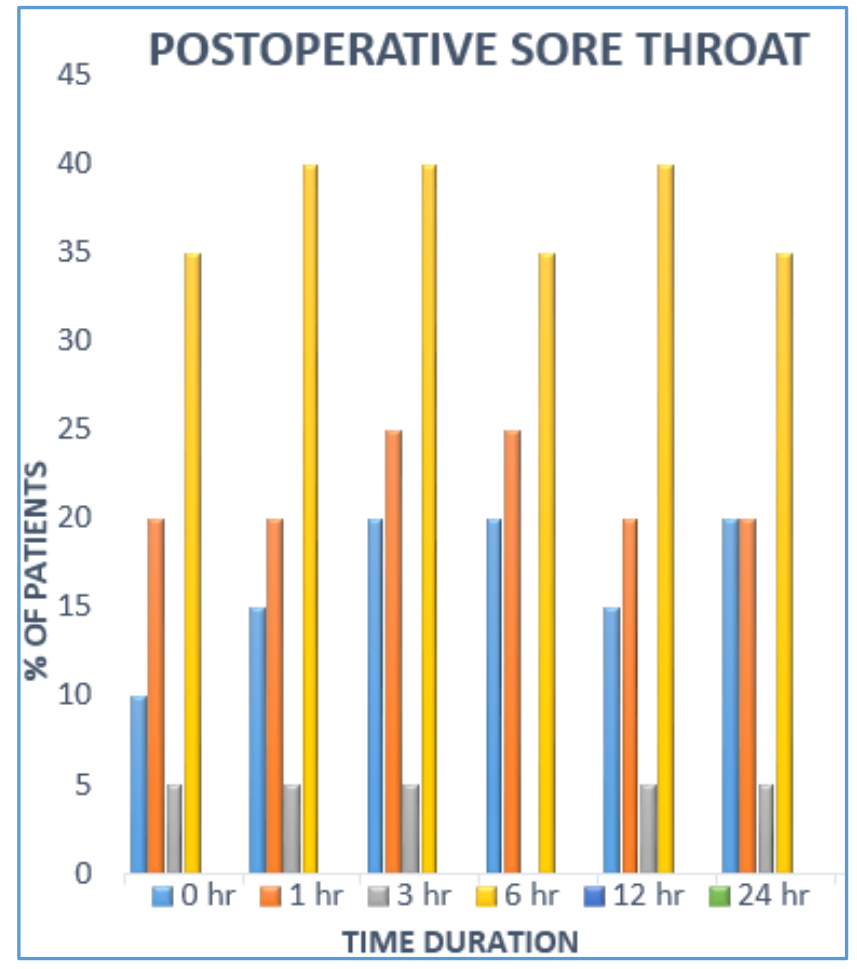

Chart 1

(1 st $^{\text {st }}$ is is for Group D, 2nd for Group K, $3^{\text {rd }}$ for Group KD and last is for Group P).

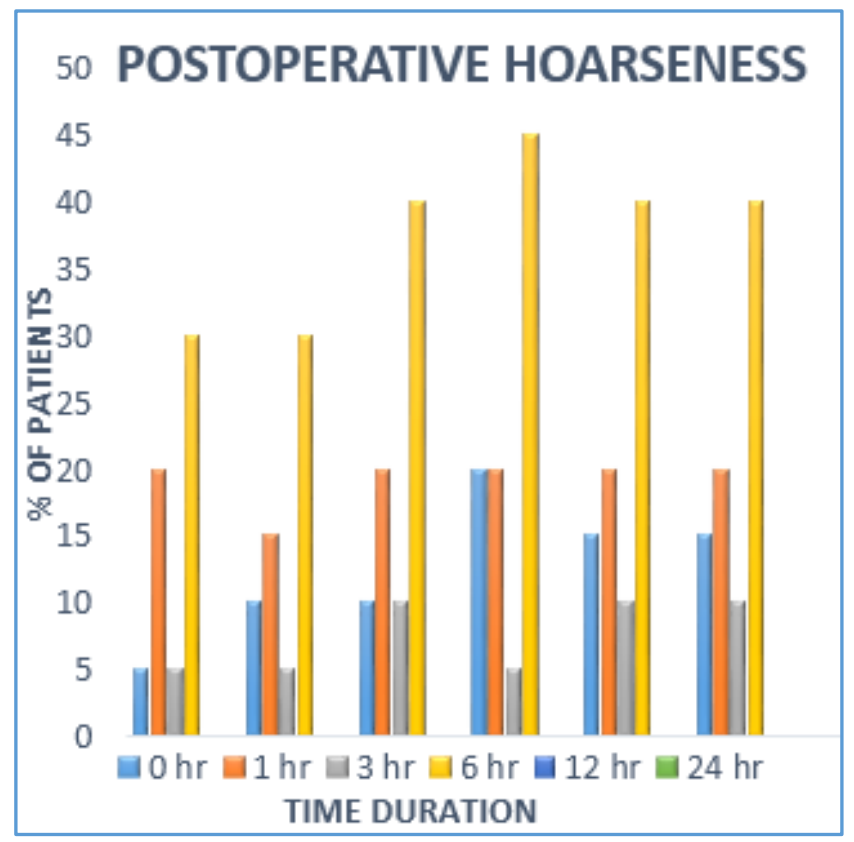

Chart 2

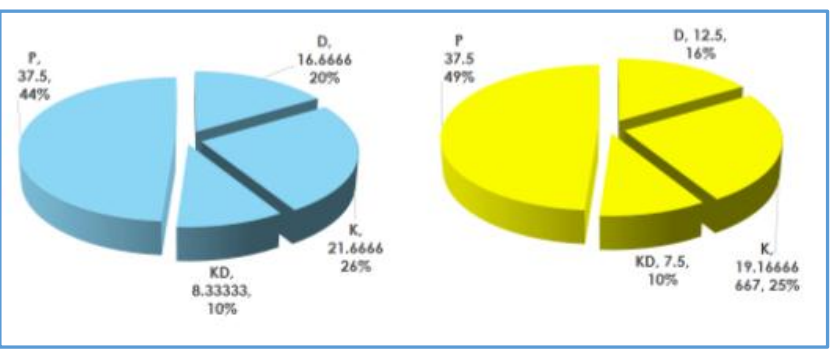

Diagram 1. Pie Diagram showing the Average \% of

Patients suffering from POST and Hoarseness upto 24 hrs. after Tracheal Extubation

\section{DISCUSSION}

- The results of this study demonstrated that the incidence and severity of POST and hoarseness were decreased in each one of Groups of KD and K and D compared with Group $\mathrm{P}$ at all times during $24 \mathrm{hrs}$. after tracheal extubation. So ketamine gargle combined with $0.2 \mathrm{mg} / \mathrm{kg}$ of dexamethasone was more effective than using each drug alone for reducing sore throat and hoarseness at all times after tracheal extubation for up to $24 \mathrm{hrs}$.

- Several contributing factors for sore throat after surgery have been reported including patient's sex, age, ET tube size, cuff design and intracuff pressure.[8,9,10] In this study, no correlation was observed between them.

- $\quad$ POST is mediated by an aseptic inflammatory process caused by:

- Irritation of the pharyngeal mucosa during laryngoscopy,

- The tracheal mucosa by the cuff of the ET tube, and

- The trauma to tissues during intubation and extubation.

\section{Ketamine}

There is an increasing amount of experimental data showing that NMDA receptors are found not only in the central nervous system but also in the peripheral nerves.[11,12] Moreover, experimental studies point out that peripherally administered NMDA receptor antagonists are involved with antinociception and anti-inflammatory cascade.[13,14] Potent antagonist of the NMDA receptor that is currently available for use in humans.[15] At low, sub-anaesthetic doses, it is relatively selective and potent antagonist of the N-methyl-Daspartate (NMDA) receptor. In the previous studies, Canbay et al[16] found that a ketamine gargle ( $40 \mathrm{mg}$ ketamine in saline $30 \mathrm{~mL}$; gargled for 30s 5 mins before induction) reduced the incidence and severity of POST in patients undergoing septorhinoplasty under general anaesthesia with endotracheal intubation, potentially because of local antiinflammatory and anti-hyperalgesic effect of ketamine (as a potent antagonist of the NMDA receptor).

\section{Dexamethasone}

Potent corticosteroid with analgesic and anti-inflammatory effects have a prophylactic effect on post-operative nausea and vomiting, prescribed for the treatment of a sore throat resulting from tracheal mechanical irritation due to its modulating effects of tissue oedema and pain.[17]

\section{Mechanism of Anti-Inflammatory Activity}

- Inhibition of leukocyte migration.

- Maintenance of cell membrane integrity.

- Attenuation of lysosome release.

- Reduction of fibroblast proliferation. $[18,19]$

- On the other hand, Parket al[20] showed that the prophylactic use of $0.2 \mathrm{mg} / \mathrm{kg}$ of dexamethasone significantly decreases the incidence and severity of sore throat and hoarseness $1 \mathrm{hr}$. to $24 \mathrm{hrs}$. after tracheal extubation of a DLT.

With respect to these findings, we propose that ketamine gargle plus IV dexamethasone is more effective than using 
alone in reducing the incidence and severity of POST and hoarseness, perhaps due to their synergistic effects.

\section{CONCLUSION}

For reducing the incidence and severity of POST and hoarseness, the administration of $40 \mathrm{mg}$ ketamine mix with $30 \mathrm{~mL}$ NS gargle combined with IV $0.2 \mathrm{mg} / \mathrm{kg}$ dexamethasone was more effective than using each of these drugs alone at all times after tracheal extubation upto $24 \mathrm{hrs}$.

\section{REFERENCES}

[1] Chandler M. Tracheal intubation and sore throat: a mechanical explanation. Anaesthesia 2002;57(2):15561.

[2] Al-Qahtani AS, Messahel FM. Quality improvement in anesthetic practice - Incidence of sore throat after using small tracheal tube. Middle East J Anesthesiol 2005;18(1):179-83.

[3] Honarmand A, Safavi M. Beclomethasone inhaler versus intravenous lidocaine in the prevention of postoperative airway and throat complaints: a randomized, controlled trial. Ann Saudi Med 2008;28(1):11-6.

[4] Ogata J, Minami K, Horishita T, et al. Gargling with sodium azulene sulfonate reduces the postoperative sore throat after intubation of the trachea. Anesth Analg 2005;101(1):290-3.

[5] Sumathi PA, Shenoy T, Ambareesha M, et al. Controlled comparison between betamethasone gel and lidocaine jelly applied over tracheal tube to reduce postoperative sore throat, cough and hoarseness of voice. Br J Anaesth 2008;100(2):215-8.

[6] Maruyama K, Sakai H, Miyazawa H, et al. Sore throat and hoarseness after total intravenous anaesthesia. $\mathrm{Br}$ J Anaesth 2004;92(4):541-3.

[7] Thomas S, Beevi S. Dexamethasone reduces the severity of postoperative sore throat. Can J Anaesth 2007;54(11):897-901.

[8] Higgins PP, Chung F, Mezei G. Postoperative sore throat after ambulatory surgery. Br J Anaesth 2002;88(4):582-4.

[9] Stout DM, Bishop MJ, Dwersteg JF, et al. Correlation of endotracheal tube size with sore throat and hoarseness following general anesthesia. Anesthesiology 1987;67(3):419-21.
[10] Combes X, Schauvliege F, Peyrouset O, et al. Intracuff pressure and tracheal morbidity: influence of filling with saline during nitrous oxide anesthesia. Anesthesiology 2001;95(5):1120-4.

[11] Carlton SM, Coggeshall RE. Inflammation-induced changes in peripheral glutamate receptor populations. Brain Res 1999;820(1-2):63-70.

[12] Carlton SM, Zhou S, Coggeshall RE. Evidence for the interaction of glutamate and NK1 receptors in the periphery. Brain Res 1998;790(1-2):160-9.

[13] Berrino L, Oliva P, Massimo F, et al. Antinociceptive effect in mice of intraperitoneal $\mathrm{N}$-methyl-D-aspartate receptor antagonists in the formalin test. Eur J Pain 2003;7(2):131-7.

[14] Zhu MM, Zhou QH, Zhu MH, et al. Effects of nebulized ketamine on allergen-induced airway hyperresponsiveness and inflammation in actively sensitized Brown-Norway rats. J of Inflamm (Lond) 2007;4:10.

[15] Chizh BA. Low dose ketamine: a therapeutic and research tool to explore N-methyl-D-aspartate (NMDA) receptor-mediated plasticity in pain pathways. J Psychopharmacol 2007;21(3):259-71.

[16] Canbay O, Celebi N, Sahin A, et al. Ketamine gargle for attenuating postoperative sore throat. $\mathrm{Br} \mathrm{J}$ Anaesth 2008;100(4):490-3.

[17] Baxendale BR, Vater M, Lavery KM. Dexamethasone reduces pain and swelling following extraction of third molar teeth. Anaesthesia 1993;48(11):961-4.

[18] Deming MV, Oech SR. Steroid and antihistaminic therapy for post intubation subglottic edema in infants and children. Anesthesiology 1961;22:933-6.

[19] Haynes RC. Adrenocorticotropic hormones: adrenocortical steroids and their synthetic analogues: inhibitors of the synthesis and actions of adrenocortical hormones. In: Goodman A, Rall T, Nies A. eds. The pharmacological basis of therapeutics. $8^{\text {th }}$ edn. New York: Pergamon Press 1990: p. 1431-62.

[20] Park SH, Han SH, Do SH, et al. Prophylactic dexamethasone decreases the incidence of sore throat and hoarseness after tracheal extubation with a double-lumen endobronchial tube. Anesth Analg 2008;107(6):1814-8. 